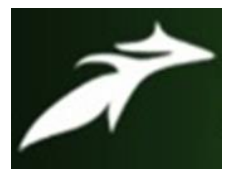

Musani Rama Subba Reddy et al, International Journal of Advances in Agricultural Science and Technology,

Vol.7 Issue.11, November-2020, pg. 60-69

ISSN: 2348-1358

Impact Factor: 6.057

NAAS Rating: 3.77

\title{
KNOWLEDGE AND ADOPTION OF PRODUCTION PRACTICES AMONG CHICKPEA GROWERS OF ANDHRA PRADESH
}

\author{
Musani Rama Subba Reddy ${ }^{1}$; Dr. Syed.H.Mazhar ${ }^{2}$; Sravan Naga Parimala Kumar K ${ }^{3}$; \\ Dr. Jahanara ${ }^{4}$ Dr. Dipak Kumar Bose ${ }^{5}$ \\ ${ }^{1} \mathrm{PG}$ Scholar, ${ }^{2}$ Associate Professor, ${ }^{3} \mathrm{PG}$ Scholar, ${ }^{4} \mathrm{HOD}$ of Extension and Communication, ${ }^{5}$ Associate Professor \\ Department of Agriculture Extension and Communication \\ Naini Agricultural Institute \\ Sam Higginbottom University of Agriculture Technology and Sciences \\ Prayagraj (Allahabad)-211007 \\ E-mail: ramureddy275@gmail.com \\ DOI: 10.47856/IJAAST.2020.v07i11.009
}

\begin{abstract}
India is the largest producer of pulses in the world. Pulses ensures food security with its rich source of protein. To feed the growing population of India, the production of pulses also need to be increased. Hence, in order to improve the production and productivity of pulses, the knowledge and adoption level of pulse growers should be learnt to understand the technological gap exists in between them. Among various pulse crops, chickpea has been widely cultivated. Thus, the knowledge and adoption level of production practices on chickpea among the chickpea growers of Kurnool, Andhra Pradesh was studied. Twelve villages from six mandals of three blocks of Kurnool district constitute the 120 chickpea growers. The primary data were gathered with the help of structured interview schedule through persona interview during 2019-2020. The findings revealed that chickpea growers had medium level of knowledge and adoption of production practices of chickpea because of medium level of innovative proneness, farm power and social participation. Hence, it was recommended to conduct training programmes and awareness campaigns to improve the knowledge and adoption of various production practices, which in turn increase the production and productivity of chickpea.
\end{abstract}

Keywords: Kurnool, Chickpea cultivation, Chickpea growers, Knowledge and adoption level, Production practices, Andhra Pradesh.

\section{INTRODUCTION}

Agriculture serves as the 'backbone of India', as it contributes 18 per cent of its income to GDP of our Nation and additionally provides employment to a more than half of the Indian population (Madhusudhan, 2015). Simultaneously, evolution and availability of farm technologies led to increase in agricultural growth. Among the highly populated countries, India secures second rank (Census, 2011). In order to feed the growing population of India, it becomes evident to ensure food security, which can be done through improving productivity of pulses. Pulses are regarded as the important food crops because of their high protein content. Subsequently, India is the largest producer of pulses in the world with chickpea (36\%), pigeon pea (17\%), mung bean (8\%), urban (13\%), lentil (7\%), and field pea (5\%). 


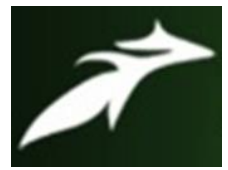

Musani Rama Subba Reddy et al, International Journal of Advances in Agricultural Science and Technology, Vol.7 Issue.11, November-2020, pg. 60-69

ISSN: 2348-1358

Impact Factor: 6.057

NAAS Rating: 3.77

Chick pea (Cicer arietinum) commonly known as 'Bengal gram' (English) and 'Channah' (Hindi) belongs to the family Leguminosae. It is widely cultivated in India as it serves as a good source of protein. The major chickpea growing states of India were Madhya Pradesh, Uttar Pradesh, Maharashtra, Andhra Pradesh, Rajasthan, Karnataka, Chhattisgarh, Bihar, and Haryana. The chickpea in India is cultivated over an area of 28.28 Million hectares and yields about 22.995 Million tines with productivity of $767 \mathrm{~kg} / \mathrm{ha}$ (Ministry of India, 2016-17). In addition to this, it can be understood that area and production of pulses contribute 30 and 37 per cent to Nation respectively.

Madhya Pradesh serves as the largest producer in the country (40\% of total production), while Rajasthan (14\%), Maharashtra (10\%), Uttar Pradesh (9\%), and Andhra Pradesh (7\%) contribute respectively. In Andhra Pradesh, chickpea was mostly cultivated in districts of Kurnool, Prakasham and Guntur; over an area of 6.38 lakh hectares with an annual production of 9.37 lakh tones with a productivity of $1469 \mathrm{Kg}$ per hectare. Though the area under chickpea was high, it does not meet the demand of people due to low production and productivity. The chickpea yield had remained stagnant over a long time and it depicts that there is a gap between the knowledge and adoption of chickpea production practices. Hence, a detailed study on the knowledge and adoption behavior of chickpea growers on the production practices helps to understand the extent of knowledge the farmers possess and the extent of adoption.

Similar studies by Pandhre et.al., (2012) observed that 62 per cent and 68 per cent of beneficiaries and non-beneficiaries were middle aged with 26.66 per cent and 22 per cent of beneficiaries and non-beneficiaries were educated up to higher secondary level. Pandey et.al., (2013) found that nearly half of the respondents (49\%) were middle aged. In addition to this, Sharma et.al., (2015) identified that most of the respondents were middle aged with medium level of education (60\%). Dakhad (2016) from his study, observed that majority of respondents had high farming experience (45\%). Singh et.al., (2016) identified that most of the chickpea growers were middle aged $(66.66 \%)$ with primary level of education $(38.33 \%), 70.83$ per cent of 


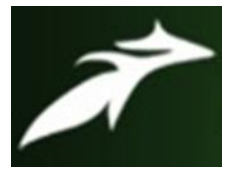

Musani Rama Subba Reddy et al, International Journal of Advances in Agricultural Science and Technology, Vol.7 Issue.11, November-2020, pg. 60-69

ISSN: 2348-1358

Impact Factor: 6.057

NAAS Rating: 3.77

chickpea growers had medium annual income from medium size of land holding (55\%). Padiyar (2017) reported that nearly half of the respondents earn high annual income from greengram (46.67\%), low farm power (40\%).

Khatik (2017) observed that nearly two-third of respondents had medium level of annual income $(67.5 \%)$ with medium level of farm power $(70 \%)$ and small farm size $(47.5 \%)$, medium level of information source utilization (55\%), medium level of mass media participation (73.75\%), medium level of scientific orientation (72.5\%), medium level of economic motivation (76.25\%). Singh and Hansra (2018) from their study observed that medium level of knowledge (48\%) followed by medium level of adoption (47.33\%). Gautam et.al., (2015) identified that there exists a strong and positive relationship between knowledge level and education, land holding; no significant relationship between herd size and knowledge level; moderate association between social participation and knowledge level. Sharma et.al., (2015) revealed that the variables like education, annual income, socio-economic status, economic motivation, risk preference, innovativeness and level of knowledge were positively related to adoption behavior.

\section{Statement of the Problem}

Kurnool is one of the districts of Andhra Pradesh, where chick pea was found to be the main crop. Even though, the area under cultivation of chickpea is constantly increasing in Kurnol, the production and productivity remains the same, even after the several efforts by govt. functionaries and reputed NGOs. In turn, it depicts that there is a gap between the knowledge and adoption of chickpea production practices. Hence, a detailed study on the knowledge and adoption behavior of chickpea growers on the production practices helps to understand the extent of knowledge the farmers possess and the extent of adoption. With this background, the following objectives were formulated. 


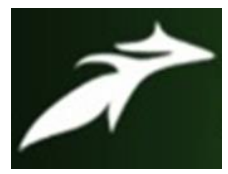

Musani Rama Subba Reddy et al, International Journal of Advances in Agricultural Science and Technology,

Vol.7 Issue.11, November-2020, pg. 60-69

ISSN: 2348-1358

Impact Factor: 6.057

NAAS Rating: 3.77

The objectives of the study were as follows,

- To ascertain the socio-economic profile of the respondents.

- To access the knowledge and adoption of recommended chickpea production practices by the respondents.

\section{METHODOLOGY}

The present study was conducted at Kurnool district of Andhra Pradesh. Kurnool district was purposively selected because of the adequate concentration of chickpea growers residing in the district. Out of 14 taluks in Kurnool district, Banaganapalle taluk was selected purposively. Among the 5 mandals in Banaganapalle taluk, sanjamala, owk and koilakuntla mandals were randomly selected (Random sampling method). From each mandal, two villages constitute six villages under study area. The farmers whose main crop was chickpea were regarded as chickpea growers and the list of chickpea growers were gathered with the help of RAEO's and other government officials. From each of the village, 20 chickpea growers were randomly selected, thus make 120 chickpea growers as respondents. The secondary data was gathered from RAEO's, other government officials, survey reports, available literature and previous studies. Meanwhile, the primary data were gathered from the chickpea growers with the help of structured interview schedule through personal interview method during 2019-2020.

\section{RESULTS AND DISCUSSION}

The gathered data was tabulated, distributed and analyzed with suitable statistical tools. The findings of the study were presented below. The socio-economic profile of the chickpea growers was studied with the characteristics like age, education, family size, annual income, land holding, farm power, social participation, economic motivation, innovative proneness, risk orientation, mass media exposure and extension contact. The results were presented in table.1. 


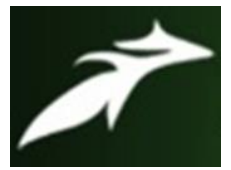

Musani Rama Subba Reddy et al, International Journal of Advances in Agricultural Science and Technology,

Vol.7 Issue.11, November-2020, pg. 60-69

ISSN: 2348-1358

Impact Factor: 6.057

NAAS Rating: 3.77

Table.1. Socio-economic profile of the chickpea growers

\begin{tabular}{|c|c|c|c|c|}
\hline \multirow[t]{2}{*}{ S. No. } & \multirow[t]{2}{*}{ Characteristics } & \multirow[t]{2}{*}{ Category } & \multicolumn{2}{|c|}{ Response } \\
\hline & & & Number & Per cent \\
\hline \multirow[t]{3}{*}{1} & \multirow[t]{3}{*}{ Age } & Young age & 30 & 25.00 \\
\hline & & Middle age & 55 & 45.84 \\
\hline & & Old age & 35 & 29.16 \\
\hline \multirow[t]{7}{*}{2} & \multirow[t]{7}{*}{ Educational status } & Illiterate & 14 & 11.67 \\
\hline & & Only read and write & 8 & 6.67 \\
\hline & & Primary & 27 & 22.50 \\
\hline & & Middle & 19 & 15.83 \\
\hline & & High school & 23 & 19.67 \\
\hline & & Higher secondary & 10 & 8.33 \\
\hline & & Graduation or More & 19 & 15.83 \\
\hline \multirow[t]{3}{*}{3} & \multirow[t]{3}{*}{ Family size } & Small (Up to 3 members) & 10 & 8.33 \\
\hline & & Medium (4-11 members) & 92 & 76.67 \\
\hline & & Large (Above 11 members) & 18 & 15.00 \\
\hline \multirow[t]{4}{*}{4} & \multirow[t]{4}{*}{ Annual income } & Low income (Below Rs. 17000) & 15 & 12.50 \\
\hline & & Semi-medium (Rs.17001 to 34000) & 17 & 14.17 \\
\hline & & $\begin{array}{l}\text { Medium income (Rs. } 34001 \text { to } \\
51000)\end{array}$ & 24 & 20.00 \\
\hline & & High income (Above Rs. 51000) & 64 & 53.33 \\
\hline \multirow[t]{5}{*}{5} & \multirow[t]{5}{*}{ Land holding } & Marginal farmers (Up to 2.5 ha) & 65 & 54.16 \\
\hline & & Small farmers (2.51 to $5 \mathrm{ha})$ & 32 & 26.67 \\
\hline & & Semi-medium farmers (5.01 to $10 \mathrm{ha})$ & 14 & 11.67 \\
\hline & & Medium farmers (10.01 to $25 \mathrm{ha})$ & 9 & 7.50 \\
\hline & & Large farmers (Above 25 ha) & 0 & 0.00 \\
\hline \multirow[t]{3}{*}{6} & \multirow[t]{3}{*}{ Social participation } & Member & 56 & 46.67 \\
\hline & & Office bearer & 20 & 16.67 \\
\hline & & Non-member /non office bearer & 44 & 36.66 \\
\hline \multirow[t]{3}{*}{7} & \multirow[t]{3}{*}{ Farm power } & Low farm power (Up to 2) & 22 & 18.33 \\
\hline & & Medium farm power (3 to 6) & 73 & 60.83 \\
\hline & & High farm power (Above 6) & 14 & 20.83 \\
\hline \multirow[t]{2}{*}{8} & \multirow{2}{*}{$\begin{array}{l}\text { Economic } \\
\text { motivation }\end{array}$} & Low (up to 17) & 32 & 26.67 \\
\hline & & Medium (17 to 23 ) & 66 & 55.00 \\
\hline
\end{tabular}




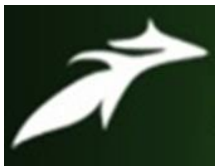

Musani Rama Subba Reddy et al, International Journal of Advances in Agricultural Science and Technology, Vol.7 Issue.11, November-2020, pg. 60-69

ISSN: 2348-1358

Impact Factor: 6.057

NAAS Rating: 3.77

\begin{tabular}{|c|c|c|c|c|}
\hline & & High (Above 23) & 22 & 18.33 \\
\hline \multirow[t]{3}{*}{9} & \multirow{3}{*}{$\begin{array}{l}\text { Innovative } \\
\text { proneness }\end{array}$} & Low (Up to 23 ) & 32 & 26.67 \\
\hline & & Medium (23 to32) & 64 & 53.33 \\
\hline & & High (Above 32) & 24 & 20.00 \\
\hline \multirow[t]{3}{*}{10} & \multirow[t]{3}{*}{ Risk orientation } & Low (Up to15) & 15 & 12.50 \\
\hline & & Medium (15 to 22$)$ & 88 & 73.33 \\
\hline & & High (Above 22) & 17 & 14.17 \\
\hline \multirow[t]{2}{*}{11} & \multirow{2}{*}{$\begin{array}{c}\text { Mass media } \\
\text { exposure }\end{array}$} & Subscriber/ Owned & 99 & 82.50 \\
\hline & & Non-subscriber/ Not-owned & 21 & 17.50 \\
\hline \multirow[t]{3}{*}{12} & \multirow[t]{3}{*}{ Extension contact } & Low (up to 2) & 67 & 55.83 \\
\hline & & Medium (2 to 4$)$ & 27 & 22.50 \\
\hline & & High (Above 4) & 26 & 21.67 \\
\hline
\end{tabular}

From table.1, it can be understood that nearly half of the chickpea growers were middle aged $(45.84 \%)$, followed by old $(29.16 \%)$ and young $(25 \%)$ age chick pea growers. They were educated up to primary school $(22.50 \%)$, followed by high school (19.67\%), middle school $(15.83 \%)$, graduation $(15.83 \%)$, illiterates $(11.67 \%)$, higher secondary $(8.33 \%)$ and only 6.67 per cent of chick pea growers can read and write. Simultaneously, more than three-fourth of the chick pea growers had medium size family $(76.67 \%)$, followed by large $(15 \%)$ and small $(8.33 \%)$ size of family. More than half of them earn high level of income $(53.33 \%)$, followed by medium (20\%), semi-medium (14.17\%) and low (12.50\%) level of income respectively. In the meanwhile, majority of the chickpea growers had marginal level of land holding (54.16\%), followed by small size (26.67\%), semi-medium size (11.67) and medium size (7.50\%) size of land holding.

Consequently, nearly half of the chickpea growers had membership in social organization (46.67\%), followed by non-member / non-office bearer (36.66\%) and office bearer (16.67\%) percent as office bearer. In addition to this, it can be seen that 80 per cent of the chick pea growers never participated in the gram panchayat, whereas 11.60 per cent of them were occasionally participate, 8.33 per cent of them regularly participate. Simultaneously, 85 per cent 


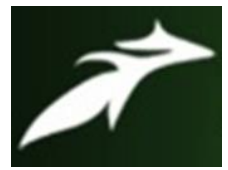

Musani Rama Subba Reddy et al, International Journal of Advances in Agricultural Science and Technology, Vol.7 Issue.11, November-2020, pg. 60-69

ISSN: 2348-1358

Impact Factor: 6.057

NAAS Rating: 3.77

of the chick pea growers never participate in youth club, followed by occasionally participation $(10 \%)$ and regular participation (5\%). As far as participation, 82.50 per cent never participate in self help groups, where 10.83 per cent and 6.66 per cent of chick pea growers participate occasionally and regularly. Further, 92.50 per cent of the respondents 'Never' participate in Other organizations (like Dairy cooperatives, Saving groups) followed by 'Occasional' (4.16\%) and 'Regular' (3.33\%).

Among the total chickpea growers, most of them had medium farm power $(60.83 \%)$, followed by high farm power (20.83\%) and low farm power (18.33\%) per cent respectively. More than half of the farmers had medium level of economic motivation (55\%), followed by low (26.67\%) and high (18.33\%) respectively. Subsequently, it can be observed that 53.33 per cent of farmers had medium level of innovative proneness, followed by low (26.67\%) and high (20\%) level of innovative proneness. Simultaneously, nearly three-fourth of the farmers had medium level of risk orientation, followed by high (14.17\%) and low (12.50\%) of risk orientation respectively. It can be seen from the table.1, that majority of the farmers were subscriber / owner of mass media sources $(82.50 \%)$, while the remaining $(17.50 \%)$ were non-subscriber or not an owner of mass media sources. Eventually, more than half of the chick pea growers $(55.83 \%)$ had low level of extension contact, followed by medium (22.50\%) and high (21.67\%) level of extension participation in various extension activities. Similar findings were reported by Pandhre et.al., (2012), Pandey et.al., (2013), Sharma et.al., (2015), Khatik (2017) and Singh and Hansra (2018).

The knowledge level of chickpea growers on various production practices like sowing, space management, irrigation, weeding, fertilizer usage, pesticide and insecticide application, etc. The data collected were tabulated and analyzed; the results were presented in table.2. 


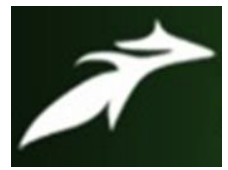

Musani Rama Subba Reddy et al, International Journal of Advances in Agricultural Science and Technology,

Vol.7 Issue.11, November-2020, pg. 60-69

ISSN: 2348-1358

Impact Factor: 6.057

NAAS Rating: 3.77

Table.2. Knowledge level of chickpea growers on production practices

\begin{tabular}{|c|l|c|c|}
\hline S. No. & \multicolumn{1}{|c|}{ Categories } & No. of chickpea growers $(\boldsymbol{f})$ & Percent (in \%) \\
\hline 1 & Low (up to 17) & 35 & 29.16 \\
\hline 2 & Medium (17to 34) & 55 & 45.84 \\
\hline 3 & High (Above 34) & 30 & 25.00 \\
\hline
\end{tabular}

From table.2, it can be seen that nearly half of the chickpea growers $(45.84 \%)$ had medium level of knowledge on production practices of chickpea, followed by low level of knowledge $(29.16 \%)$ and high level of knowledge (25\%) on production practices.

The probable reason might be the fact that chickpea has been cultivated as major crop in the Kurnool region and medium level of education led to medium level of knowledge on various production practices of chickpea growers. The results were similar with the findings of Gautam et.al., (2015).

Table.3. Adoption level of chickpea growers on production practices

\begin{tabular}{|c|l|c|c|}
\hline S. No. & \multicolumn{1}{|c|}{ Categories } & No. of chickpea growers $(\boldsymbol{f})$ & Percent (in \%) \\
\hline 1 & Low (Up to 17) & 37 & 30.83 \\
\hline 2 & Medium (17to 34) & 64 & 53.33 \\
\hline 3 & High (Above34) & 19 & 15.84 \\
\hline
\end{tabular}

From table.3, it can be understood that, more than half of the chickpea growers had medium level of adoption (53.33\%), followed by low (30.83\%) and high (15.84\%) level of production practices in cultivation of chickpea. 


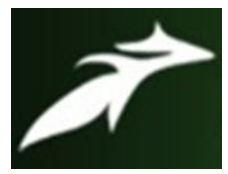

Musani Rama Subba Reddy et al, International Journal of Advances in Agricultural Science and Technology, Vol.7 Issue.11, November-2020, pg. 60-69

ISSN: 2348-1358

Impact Factor: 6.057

NAAS Rating: 3.77

The possible reason might be the fact that, medium level of innovative proneness, farm power and social participation led to increased rate of adoption on various production practices in cultivation of chickpea. Similar findings were reported by Sharma et.al., (2015).

\section{CONCLUSION}

From the present study, it can be learnt that majority of the chickpea growers in Kurnool district were middle aged with primary school education and possessed medium size of family with marginal size of land holding. Subsequently, they had medium farm power which earns high annual income. In addition to this, most of the chickpea growers member in various social organizations with low extension contact and subscription for various mass media sources. They also had medium level of economic motivation, innovative proneness, risk orientation and resulted in medium level of knowledge and adoption of various production practices of chickpea. Thus, it is also recommended to conduct more training programmes and awareness campaigns to increase production and productivity of chickpea, since it remains as the major crop of Kurnool. Eventually, new policies to provide subsidy for pulse growers should be implemented.

\section{REFERENCES}

[1]. Dakhad Santosh (2016). "A study on training needs of chickpea growers in Morena block of Morena district M.P.” M.Sc. (Ag.) Thesis Unpublished to R.V.S.K.V.V, Gwalior.

[2]. Khatik, Akash (2017). "A Study on Differential Impact of Frontline Demonstration on Scientific Temperament of Soyabeen Growers in Shivpuri District of M.P.” M.Sc. (Ag.) Thesis Unpublished RVSKVV, Gwalior.

[3]. Madhusudhan, L. (2015). Agriculture role on indian economy. Business and Economics Journal, 6(4), 1.

[4]. Padiyar, Kavita (2017). "Impact of Front Line Demonstration on knowledge and adoption level among green gram growers in Dewas District (M.P.)". M.Sc. (Ag.) Thesis unpublished, RVSKVV, Gwalior (M.P.).

[5]. Pandey C.D., Soni Artin and Chouhan N.M (2013). Awareness among farmers about Krishi Vigyan Kendra knowledge resource centre in Tapi district Gujarat J. of Ext. Edu 24 : 114-119. 


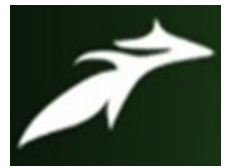

Musani Rama Subba Reddy et al, International Journal of Advances in Agricultural Science and Technology,

Vol.7 Issue.11, November-2020, pg. 60-69

ISSN: 2348-1358

Impact Factor: 6.057

NAAS Rating: 3.77

[6]. Pandhre S.P., Nadre K.R., Deshmukh R.S. and Bhosale P.B. (2012). "Adoption of Krishi Vigyan Kendra recommended practices". Agriculture update, 7 (182): 85-91.

[7]. Patodiya, R.S. (2018). "Knowledge and Adoption of Scientific Wheat Cultivation Practices in Rajasthan". Indian Res. J. Ext. Edu. 18 (1): 93-95.

[8]. Sharma, Karamjit., Dhaliwal, N.S. and Kumar, Ajay (2015). "Analysis of Adoption and Constraints Perceived by Small Paddy Growers in Rice Production Technologies in Muktsar District of Punjab State, India”. Indian Res. J. Ext. Edu., 15 (2): 20-23.

[9]. Singh, Bagri Uttam., Singh, Kinjulck and Singh, C.J. (2016). "Extent of awareness regarding natural resources management among rural women in Shadol District of M.P.". Indian Journal of Extension Education 52 (1\&2): 111-113. 